\title{
The energy question in the Belgian daily press during 2010: the role of region, newspaper type and newspaper section
}

\section{Pieter Maeseele, Karel Deneckere, Koen Panis and Steve Paulussen}

\begin{abstract}
The literature illustrates how media research on the energy question is characterized by a limited focus on separate energy options, resulting in a lack of research into the diversity of and mutual relations between various energy options. This paper reports on a quantitative content analysis of eight Belgian newspapers ( $N=1181)$, focusing on whether certain energy options are systematically more covered in certain regions, types of newspapers and/or types of newspaper sections. The results show that five energy options dominate the debate and that there are minimal differences per region, but remarkable differences between types of newspapers and newspaper sections.
\end{abstract}

Keywords

Images and representations of science and technology, Public communication of and discourses on science and technology, Science and media

The energy question seems to be increasingly gaining social importance. Various issues such as oil and gas prices, subsidies and taxes, the energy bill, the future of nuclear energy, the (potential) use of shale gas, new onshore or offshore windmill projects, embargoes and diplomatic tensions, etc., are appearing regularly in the public eye. Furthermore, the Western world is experiencing a strong feeling of urgency on the necessity to renew energy supplies thoroughly and instantly. A clear example of this sense of urgency is observed in the Green Paper, a European energy policy framework formulated in 2006, expressing the need for a renewed infrastructure as a cause of the changing energy landscape [Commission of the European Communities, 2006]. Therefore, this policy framework focuses on six important challenges in the European energy landscape: (i) the urgent need for investments to renew the infrastructure, (ii) the increasing dependence on energy import from a small number of countries, (iii) the growing global demand for energy, (iv) rising oil and gas prices, (v) global warming and (vi) the still developing European energy markets. This need also appears in the recent policy note of the Belgian federal Minister of Energy and is reflected in the following challenges: the preparation of the nuclear exit, stimulating alternative production capacity, the need for more competition on the energy market, improved transparency and more investments [Wathelet, 2012]. These policy notes have to be 
seen in the context of the European triple energy target ${ }^{1}$ aiming to (i) reduce greenhouse gas emissions by $20 \%$ in comparison with 1990 , (ii) raise the share of renewable resources in the energy production with $20 \%$, and (iii) stimulate a decrease in energy consumption by $20 \%$, all by 2020 .

Social debate on the energy question (and its actors) is significantly influenced by its representation(s) in the media. By selecting, (re)producing and (re)configuring representations that circulate in the public sphere, media influence the social acceptance of and political support for various energy options [Gamson and Modigliani, 1989]. That applies particularly, and more than ever, to questions where imperceptible risks are at stake, such as nuclear energy and climate change, because society depends to a large extent on the - often contradictory - representations in the media in order to interpret those risks [Beck, 1992; Maeseele, 2013].

Several authors have stressed how two factors are crucial in influencing the social support for a specific energy future [Ganzevles and Van Est, 2011; Nadar, 2010; Sovacool, 2013; Spreng et al., 2012]. First, it is essential to have an extensive overview of the existing energy options: in order to evaluate a certain energy option it is highly important to be informed about the available alternatives. Second, it is also of great importance to focus on the various social criteria involved in evaluating energy options, and more specifically their (i) cost, (ii) reliability, (iii) environmental and health impact, and (iv), spatial impact. However, in practice social debate is generally limited to separate energy options, which creates a fragmented and diffuse image: in this way, alternatives cannot be clearly compared and the need for a certain energy development remains unclear.

This lacuna is also strongly present in media research on the energy question. Nevertheless, there has been substantial research on the media's framing of energy issues. The first studies were published in the 1970s following the oil crisis caused by the embargo of the Organization of Petroleum Exporting Countries (OPEC) [Kepplinger and Roth, 1979; Lambeth, 1978; Murphree and Aucoin, 2010]. In the 1980s and 1990s most studies focused on nuclear accidents, such as the Three Mile Island nuclear accident in Harrisburg, U.S.A., in 1979 [Stephens and Edison, 1982] and the Chernobyl nuclear disaster in Ukraine in 1986 [Mazur, 1990]. Since the 2000s media research has diversified, focusing on climate change [Nerlich and Koteyko, 2009], the uncertain future for nuclear energy [Bickerstaff et al., 2008; Culley et al., 2010; Doyle, 2011], new energy technologies such as wind turbines and biofuels [Qu et al., 2009; Stephens, Rand and Melnick, 2009] and energy efficiency [Bolsen, 2011]. Hence, we can conclude that previous media research on the energy question also focused on just one or several - often controversial - aspects (cost, safety or the impact on the environment and health) of one energy option (nuclear energy, oil, wind turbines etc.). The media's representation of the diversity of and the mutual relations between the various options has not been researched yet.

The aim of this article is to address these lacunas by measuring the selection of and attention for specific energy options in the daily press reporting of the energy

\footnotetext{
${ }^{1}$ For more information, see the website of the European Commission, where the 2020 climate and energy package is described as "a set of binding legislation which aims to ensure the European Union meets its ambitious climate and energy targets for 2020". Retrieved from http:/ / ec.europa.eu/clima/policies/package/index_en.htm.
} 
question during one year. To that end, the results are discussed of a quantitative content analysis of the reporting by eight Belgian newspapers on the energy question during $2010(\mathrm{~N}=1181)$. The research design aims at representing not only to what extent a diversity of energy options is covered in a diverse range of newspapers, but also if certain energy options are systematically more covered in certain types of newspapers (popular, financial or quality newspaper) or in certain types of newspaper sections (general news, local reporting, opinion pieces or interviews). Additionally, the Belgian case provides an opportunity to study potential cultural or political differences per region.

Belgium is divided into a Dutch-speaking and French-speaking region that each have their own media. Since the revision of the Constitution in 1980 the competencies with regards to energy have been distributed among the Regions and the Federal State. What is relevant here is article 6 section 1 VII of the special law of August 8, 1980, that lists the regional competencies [Economie, 2013]. Only those competencies that were considered to be technically and economically indivisible remained at the federal level, such as nuclear energy, the tariffs, the national equipment plan for the electricity sector, and the central infrastructure in terms of energy storage and production. Thus, all of the other aspects have become regional competencies, such as electricity and gas distribution, new energy resources (especially renewable energy production has become an important item), energy recuperation and stimulating rational energy consumption.

For contextual reasons, it is important to look at Belgium's 2010 energy mix. A clear distinction has to be made between (primary) energy consumption and production, as Belgium's production only covers a quarter of its consumption. The key figures of the Belgian Energy Observatory in Figure 1 indicate that oil $(42,0 \%)$, natural gas $(27,6 \%)$ and nuclear energy $(20,3 \%)$ are the most consumed energy resources in 2010 , followed by coal (5\%) and renewable energies and recuperation fuels (5\%). The production ${ }^{2}$ of energy, however, is divided between nuclear energy $(83 \%)$ and renewable energies and recuperation fuels (17\%). In more detail, Figure 2 shows how the renewable energy production consists of biomass ${ }^{3}(9 \%)$ for the greater part, and of hydro- or water power $(3 \%)$, wind energy ${ }^{4}(2 \%)$, solar energy ${ }^{5}(1 \%)$, anaerobic digestion (1\%) and biofuels (1\%). The category 'other' (nearly $1 \%$ ) consists of wave power, tidal and geothermal energy production.

A quantitative content analysis was conducted on a selection of eight Belgian newspapers. This selection includes four Dutch-speaking newspapers - De Standaard, De Morgen, Het Laatste Nieuws and De Tijd — and four French-speaking newspapers - Le Soir, La Libre Belgique, La Dernière Heure and L'Echo. In each Region we have two quality newspapers (De Standaard, De Morgen, Le Soir and La Libre Belgique), a popular newspaper (Het Laatste Nieuws and La Dernière Heure) and a business newspaper (De Tijd and $L^{\prime} E c h o$ ).

\footnotetext{
${ }^{2}$ The key figures for 2010 show that Belgium could supply ca. $25 \%$ of its energy need and the rest was imported. Regarding nuclear energy, which supplies almost half of the energy production, there is a statistical agreement that, although uranium is imported, nuclear heat is considered to be own production.

${ }^{3}$ Biomass = industrial waste, urban waste (renewable and non-renewable), wood, wood waste and other types of solid waste.

${ }^{4}$ Wind energy $=$ onshore and offshore together

${ }^{5}$ Solar energy $=$ photovoltaic and thermal together
} 


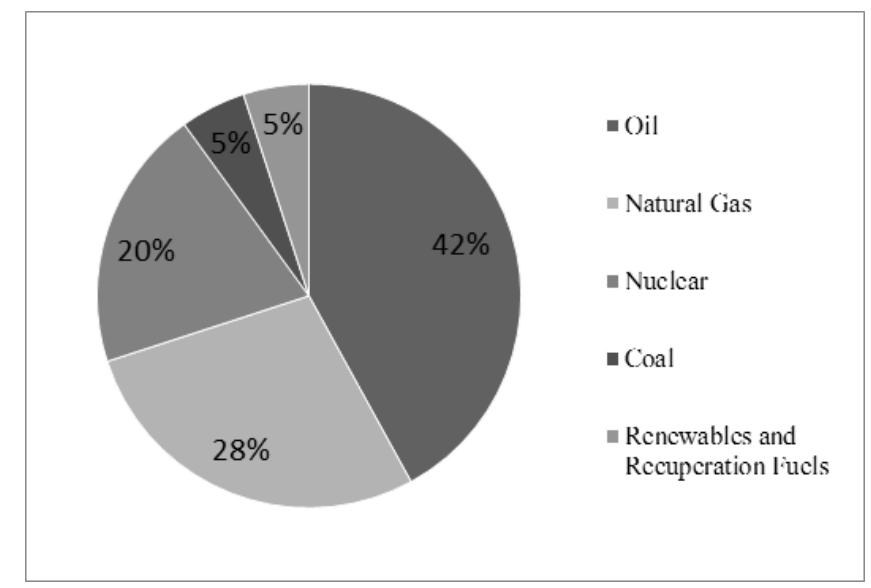

Figure 1. Primary energy consumption in Belgium in 2010.

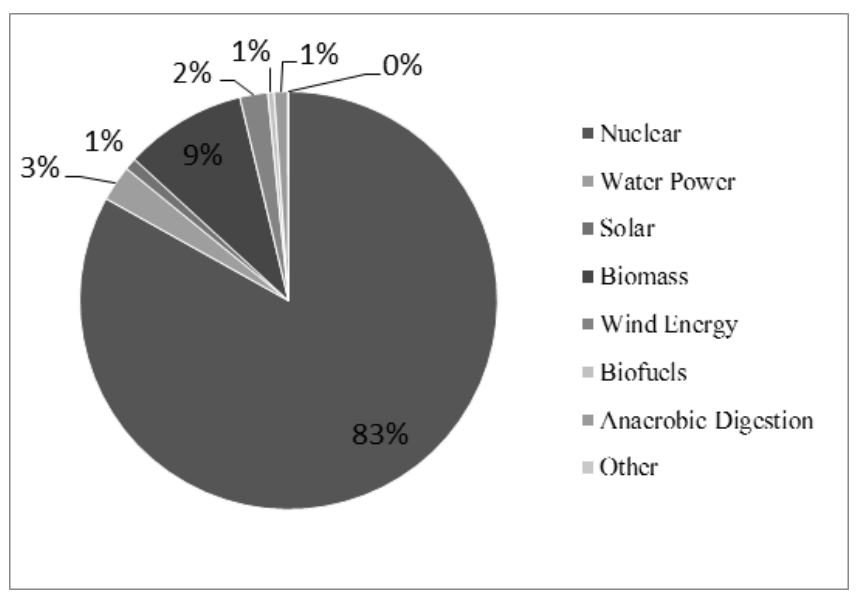

Figure 2. Energy production (heating and electricity) in Belgium in 2010.

The corpus of articles on the energy question was collected on the basis of a Dutch-speaking and French-speaking keyword list which we entered into the respective digital press databases Mediargus and Pressbanking. Using search commands in Mediargus, Pressbanking and Google, each keyword was first tested on productivity - does it give enough results? -, and selectivity - is the meaning of the word specific enough? [Schafraad, Wester and Scheepers, 2006, pp. 458, 459]. In these keyword lists we took into account a diverse range of energy resources, much-discussed energy items and big players in the energy debate. The eventual Dutch-speaking and French-speaking keyword lists include respectively sixty ${ }^{6}$ and

\footnotetext{
${ }^{6}$ Dutch-speaking keyword list: accijn $^{*}$ OR clique OR brandsto* OR kernreacto* OR kerncentral ${ }^{*}$ OR kernuitsta* OR hernieuwba* OR kernenergie OR nucleai* OR windenergi* OR gas AND energi* OR aardgas OR olie* AND energi* OR steenko* OR diesel OR benzine OR biomassa OR windmole* OR windturbin* OR "zonne-energie" OR zonnepan* OR zonnece* OR elektricitei* AND energi* OR electrabel OR "spe luminus" OR suez OR creg OR vreg OR sibelga OR infrax OR distrigas OR eandis OR fluxys OR elia OR netbeheerde* OR Co2 AND energi* OR bevoorradingszekerheid OR stookolie OR energiebelei* OR energieregulato* OR energiezuini* OR energieverbrui* OR energiekos* OR energieleverancie ${ }^{*}$ OR energieproducen* OR energiemark* OR energiebevoorradin* OR energiefactu* OR energierekenin* OR energieprij* OR biobrandsto* OR energiebesparin* OR energiebro* OR groenestroo* OR energieproducen* OR uraniumtaks.
} 
forty-five ${ }^{7}$ keywords (the maximum number of key words is adapted to the possibilities of the respective databases). Both lists were entered for a period of twelve months, namely January 1 until December 31, 2010. Next, we selected the articles on the basis of their relevance regarding 'the energy question in Belgium'. Newspaper articles mainly reporting on world news, new company-specific products or the presence of nuclear weapons, for example, were therefore not included. The final corpus consists of 1181 articles.

On the one hand, the codebook contained the selection-variables - identification number, publication date, newspaper, section, title and subtitle -, that measure the formal aspects of the individual articles. The variable 'section' comprises 'general news' (e.g. domestic and foreign news, politics and financial-economic news), 'local news', 'editorials', 'opinion pieces', 'letters to the editor', 'quote', and 'interviews'. On the other hand, the construction-variables checked which energy options were covered in the articles. The presence of energy options was scored as follows: ' 2 ' = prominently present in the article, ' 1 ' = present but not prominently or $' 0{ }^{\prime}=$ absent. If an energy option is prominently present, this means that it is either mentioned in the title or mentioned most frequently in the text. Based on a pretest on a selection of newspaper articles, the energy options included are natural gas, oil, coal, nuclear energy, non-specified classical energy, ${ }^{8}$ non-specified fossil energy, ${ }^{9}$ biofuels, biomass, geothermal energy, tidal energy, wave power, water or hydropower, onshore wind energy, offshore wind energy, non-specified wind energy, ${ }^{10}$ solar energy (i.e. photovoltaic and solar heaters), other renewable energy $^{11}$ and non-specified renewable energy. ${ }^{12}$ On the basis of the percentage test, the intra-coder reliability analysis carried out on $10 \%$ of the articles resulted in percentages between $91.83 \%$ and $100 \%$, from which we can conclude an acceptable level of reliability.

The results are discussed step by step. First, we discuss the energy options for all eight investigated newspapers together. Second, we successively make a distinction between the Dutch-speaking and the French-speaking press, the eight individual newspapers and the newspaper sections in order to find out to what extent certain energy resources are systematically more covered in certain regions, types of newspapers or types of newspaper sections.

\footnotetext{
${ }^{7}$ French-speaking keyword list: ((fourniture OR fournisseu* OR producteu* OR consommation OR verte OR coû* OR prix OR renouvelable OR solair*) AND (énergi* OR électriqu* OR électricité OR gaz OR pétrol* OR charbo* OR diesel OR essence OR mazout OR carburan* OR biocarburan*)) OR cliquet OR nucléai* OR éolie* OR photovoltaïque OR photovoltaïques OR cogénération OR ((gestionnair*AND réseau) AND énergi*) OR (sécurité AND (approvisionnement OR énergétique)) OR electrabel OR luminus OR suez OR creg OR cwape OR sibelga OR distrigas OR fluxys OR elia OR renouvelables OR "économies d'énergie" OR "économie d'énergie" OR "politique énergétique".

${ }^{8}$ Non-specified classical energy' refers to the mentioning of the total of classical energy resources (oil, natural gas, coal and nuclear energy) without further specification.

${ }^{9}$ 'Non-specified fossil energy' refers to the mentioning of the fossil energy resources put together (oil, natural gas and coal) without further specification.

${ }^{10}$ 'Non-specified wind energy' refers to the mentioning of wind energy in general, without distinction between onshore and offshore.

11 'Other renewable energy' refers to the mentioning of these renewable resources that were not included in the codebook, such as their relatively unknown identity because of the early stage of development.

${ }^{12}$ Non-specified renewable energy' refers to the mentioning of the total of possible renewable energy resources and technologies without further specification.
} 
Table 1. Prominent energy resources in the Dutch-speaking and French-speaking press.

\begin{tabular}{|c|c|c|c|c|c|c|}
\hline \multirow[b]{2}{*}{ Energy options } & \multicolumn{2}{|c|}{ General } & \multicolumn{2}{|c|}{ Dutch-speaking } & \multicolumn{2}{|c|}{ French-speaking } \\
\hline & Absolute & $\%$ & Absolute & $\%$ & Absolute & $\%$ \\
\hline Classical: & 553 & 46,8 & 251 & 43,0 & 302 & 49,8 \\
\hline Nuclear energy & 291 & 24,6 & 143 & 24,9 & 148 & 24,4 \\
\hline Natural gas & 188 & 15,9 & 68 & 11,2 & 120 & 19,8 \\
\hline Oil & 61 & 5,2 & 33 & 5,7 & 28 & 4,6 \\
\hline Carbon & 9 & 0,8 & 7 & 1,2 & 2 & 0,3 \\
\hline Fossil $S^{a}$ & 258 & 21,9 & 108 & 18,1 & 150 & 24,7 \\
\hline Fossil NS ${ }^{b}$ & 4 & 0,3 & 0 & 0,0 & 4 & 0,7 \\
\hline Fossil total & 262 & 22,2 & 108 & 18,1 & 154 & 25,4 \\
\hline Renewable: & 568 & 48,1 & 293 & 51,1 & 275 & 45,4 \\
\hline Wind energy: & 276 & 23,3 & 110 & 19,2 & 166 & 27,4 \\
\hline Onshore & 213 & 18,0 & 74 & 12,9 & 139 & 22,9 \\
\hline Offshore & 45 & 3,8 & 27 & 4,7 & 18 & 3,0 \\
\hline$N S^{b}$ & 18 & 1,5 & 9 & 1,6 & 9 & 1,5 \\
\hline Solar energy & 103 & 8,7 & 62 & 10,8 & 41 & 6,8 \\
\hline Biomass & 29 & 2,5 & 17 & 3,0 & 12 & 2,0 \\
\hline Biofuels & 7 & 0,6 & 4 & 0,7 & 3 & 0,5 \\
\hline Wave power & 7 & 0,6 & 5 & 0,9 & 2 & 0,3 \\
\hline Geothermal energy & 2 & 0,2 & 2 & 0,3 & 0 & 0,0 \\
\hline Hydropower & 2 & 0,2 & 0 & 0,0 & 2 & 0,3 \\
\hline Tidal energy & 1 & 0,1 & 1 & 0,2 & 0 & 0,0 \\
\hline Renewable $S^{a}$ & 427 & 36,2 & 201 & 35,1 & 226 & 37,3 \\
\hline Renewable NS ${ }^{b}$ & 134 & 11,3 & 88 & 15,3 & 46 & 7,6 \\
\hline Renewable other & 7 & 0,6 & 4 & 0,7 & 3 & 0,5 \\
\hline No option & 60 & 5,1 & 31 & 5,9 & 29 & 4,8 \\
\hline Total & 1181 & $100 \%$ & 575 & $100 \%$ & 606 & $100 \%$ \\
\hline
\end{tabular}

\subsection{General reporting}

Table 1 gives an overview of the mutual relations between the energy options that are prominently present in all newspapers and of the mutual relations according to region. In the most left column, all energy options are summed up, sorted from most to least present for both classical and renewable energy options. In this paragraph, we focus on the second and third column showing respectively in absolute and relative numbers in how many newspaper articles an energy option is prominently present.

If we group the energy options that refer to wind energy together and exclude the (remaining) non-specified (NS) categories, then five energy options appear to dominate the debate in the Belgian newspapers during 2010: nuclear energy $(24,6 \%)$, wind energy $(23,3 \%)$, natural gas $(15,9 \%)$, solar energy $(8,7 \%)$ and oil $(5,2 \%)$. This shows that nuclear energy and wind energy together account for almost half of the reporting and the other three energy options follow each other at a certain distance. 
If we sort the energy options into classical and renewable options, then we can observe that the classical $(46,8 \%)$ and renewable $(48,1 \%)$ energy options almost balance each other and that there are significant similarities and differences within these two groups. In the group of classical energy options, nuclear energy $(24,6 \%)$ as prominent energy option is covered in more than half of the articles, followed by the fossil fuels natural gas $(15,9 \%)$, oil $(5,2 \%)$ and coal $(<1 \%)$. In other words, regarding the relations within the category of classical energy options, nuclear energy is prominently present in more articles than all fossil fuels together (291 versus 262).

In the group of the renewable energy options, we observe something similar: here wind energy $(23,3 \%)$ accounts for almost half of the articles, followed by solar energy $(8,7 \%)$ and biomass $(2,5 \%)$. The other renewable options, however, such as biofuels, wave power, geothermal energy, hydropower and tidal energy, are each present in less than 10 articles on a total of 1181 articles. It is quite notable that in almost a quarter of the articles that prominently report on renewable energy options, renewable energy dominates the article more as a general idea (non-specified renewable energy or 'renewable NS' in the table) than as a real energy option. This non-specified category of fossil fuels is only prominently present in 4 articles, the non-specified category of the renewable energy resources, however, is prominently present in 134 articles. Finally, these data show that other renewable energy options are only prominently present in 5 articles, which indicates that the prior codebook selection of energy resources effectively reflects the existing energy debate in the press.

From this, we can conclude that the energy question during 2010 in the selected Belgian newspapers is a matter of five diverse energy options, namely nuclear energy, the fossil fuels natural gas and oil and the renewable energy options wind and solar energy. The other seven energy options, namely the fossil fuel coal and the renewable options biofuels, hydropower, geothermal energy, wave power and tidal energy, are rather insignificant. The final option, biomass, is prominently present in 29 articles, giving it medium prominence.

\subsection{Reporting per region}

The other columns in Table 1 enable us to investigate if this media mix of energy options is differently covered in the newspapers of the Dutch-speaking region $(n=575)$ and of the French-speaking region $(n=606)$. The five energy options that are the most prominently present, do not change per region, however, the mutual relation does. For example, we observe that, in comparison to the Dutch-speaking newspapers, the French-speaking press publishes an almost equal number of articles on nuclear energy (in both regions about a quarter of the reporting on energy), but devotes more attention to wind energy (166 articles in the French-speaking newspapers versus 110 in the Dutch-speaking newspapers).

If we focus on the classical energy resources, we observe that a relatively larger attention to natural gas as prominent energy option in the French-speaking press is responsible for a larger attention to classical energy options, and more specifically, fossil fuels. This means that only in the Dutch-speaking press the relation between nuclear energy versus fossil fuels tends to the first, although the relation in the 
French-speaking press remains almost the same. Nonetheless, the presence of nuclear energy as prominent energy resource is still at least as strong as all fossil fuels together.

If we focus on the renewable energy options, then we observe two significant differences between the newspapers in both regions: if we have a closer look at the data on wind energy, then the French-speaking newspapers have almost twice as much attention to onshore wind energy (139 versus 74 articles). On the other hand, the idea of (non-specified) renewable energy is prominently presented almost twice as frequently in the Dutch-speaking press (88 versus 46 articles).

\subsection{Reporting per type of newspaper and type of section}

In this paragraph, we discuss to what extent certain energy resources are systematically more covered in certain types of newspapers or newspaper sections. In terms of the number of articles, Tables 2 and 3 show that in both regions financial and quality newspapers publish a lot more articles on the energy question in Belgium than popular newspapers.

Table 2. Energy resources in individual Dutch-speaking newspapers (\%).

\begin{tabular}{|c|c|c|c|c|c|}
\hline Energy resource & De Standaard & De Morgen & $\begin{array}{r}\text { Het Laatste } \\
\text { Nieuws }\end{array}$ & De Tijd & Average \\
\hline Natural gas & 8,9 & 24,2 & 4,2 & 10,6 & 11,8 \\
\hline Oil & 4,2 & 14,2 & 1,1 & 4,1 & 5,7 \\
\hline Coal & 0,5 & 0,0 & 2,1 & 2,4 & 1,2 \\
\hline Nuclear energy & 23,2 & 25,0 & 13,7 & 32,9 & 24,9 \\
\hline Classical: $\mathrm{NS}^{b}$ & 0,0 & 0,0 & 0,0 & 0,0 & 0,0 \\
\hline Fossil: $\mathrm{NS}^{b}$ & 0,0 & 0,0 & 0,0 & 0,0 & 0,0 \\
\hline Biofuels & 0,0 & 0,0 & 0,0 & 2,4 & 0,7 \\
\hline Biomass & 3,7 & 0,8 & 3,2 & 3,5 & 3,0 \\
\hline Geothermal energy & 0,0 & 0,0 & 1,1 & 0,6 & 0,3 \\
\hline Tidal energy & 0,5 & 0,0 & 0,0 & 1,2 & 0,2 \\
\hline Wave power & 1,1 & 0,0 & 2,1 & 0,6 & 0,9 \\
\hline Hydropower & 0,0 & 0,0 & 0,0 & 0,0 & 0,0 \\
\hline Wind: Onshore & 13,2 & 1,7 & 47,4 & 1,2 & 12,9 \\
\hline Wind: Offshore & 6,3 & 3,3 & 2,1 & 5,3 & 4,7 \\
\hline Wind: $\mathrm{NS}^{b}$ & 3,2 & 0,8 & 0,0 & 1,2 & 1,6 \\
\hline Solar energy & 15,3 & 5,8 & 9,5 & 10 & 10,8 \\
\hline Renewable: other & 0,0 & 1,7 & 0,0 & 1,2 & 0,7 \\
\hline Renewable: $\mathrm{NS}^{b}$ & 14,2 & 18,3 & 9,5 & 17,6 & 15,3 \\
\hline No option & 5,7 & 4,2 & 4,0 & 5,2 & 5,3 \\
\hline Total (absolute): & 190 & 120 & 95 & 170 & 575 \\
\hline
\end{tabular}

Furthermore, the differences between the individual newspapers are quite notable. In the Dutch-speaking region, we observe that, in terms of the diversity of energy options that are prominently present, the financial newspaper De Tijd published the most (13), followed by the quality newspaper De Standaard (11), the popular newspaper Het Laatste Nieuws (10), and the quality newspaper De Morgen (8). This 
indicates that neither the total number of published articles nor the type of newspaper appears to have a direct influence on the number of energy resources that are prominently present in a specific Dutch-speaking newspaper. If we focus on specific energy options, than we observe strong differences concerning the attention for wind energy: in the popular newspaper Het Laatste Nieuws, onshore wind energy $(47,4 \%)$ is prominently present in almost half of the articles, offshore wind energy, however, scores higher in the newspapers De Tijd (5,3\% versus 1,2\%, or two articles) and De Morgen (3,3\% versus 1,7\%, or two articles). Although De Standaard does not follow this relation, it does publish more articles on offshore wind energy $(6,3 \%)$ than De Tijd. Hence, the scores for wind energy are remarkably high for both De Standaard and Het Laatste Nieuws. Another notable observation is De Morgen's relatively strong attention for natural gas $(24,2 \%)$ and oil $(14,2 \%)$ in comparison with wind and solar energy $(5,8 \%)$, and Het Laatste Nieuws' relatively low attention for nuclear energy $(13,7 \%)$. De Standaard gives relatively more attention to solar energy $(15,3 \%)$.

Table 3. Energy resources in individual French-speaking newspapers (\%).

\begin{tabular}{lrrrrr}
\hline Energy resources & Le Soir & $\begin{array}{r}\text { La Libre } \\
\text { Belgique }\end{array}$ & $\begin{array}{r}\text { La Dernière } \\
\text { Heure }\end{array}$ & L'Echo & Average \\
\hline Natural gas & 22,3 & 14,3 & 11,4 & 27,1 & 19,8 \\
Oil & 4,7 & 7,5 & 1,9 & 3,6 & 4,6 \\
Coal & 0,0 & 0,0 & 0,0 & 1,0 & 0,3 \\
Nuclear energy & 17,6 & 31,7 & 10,5 & 31,3 & 24,4 \\
Classical: NS ${ }^{b}$ & 0,0 & 0,0 & 0,0 & 0,0 & 0 \\
Fossil: NS & 0,7 & 0,6 & 0,0 & 1,0 & 0,7 \\
Biofuels & 0,0 & 0,0 & 0,0 & 1,6 & 0,5 \\
Biomass & 3,4 & 1,9 & 1,9 & 1,0 & 2 \\
Geothermal energy & 0,0 & 0,0 & 0,0 & 0,0 & 0 \\
Tidal energy & 0,0 & 0,0 & 0,0 & 0,0 & 0 \\
Wave power & 0,0 & 0,6 & 0,0 & 0,5 & 0,3 \\
Hydropower & 0,0 & 1,2 & 0,0 & 0,0 & 0,3 \\
Wind: Onshore & 25,0 & 22,4 & 60,0 & 1,6 & 22,9 \\
Wind: Offshore & 2,7 & 3,7 & 0,0 & 4,2 & 3 \\
Wind: NS ${ }^{b}$ & 1,4 & 1,9 & 0,0 & 2,1 & 1,5 \\
Solar energy & 9,5 & 4,3 & 7,6 & 6,3 & 6,8 \\
Renewable: other & 0,7 & 0,0 & 1,0 & 0,5 & 0,5 \\
Renewable: NS ${ }^{b}$ & 8,1 & 6,2 & 2,9 & 10,9 & 7,6 \\
No energy option & 3,9 & 3,7 & 2,8 & 7,3 & 4,8 \\
\hline Total (absolute): & 148 & 161 & 105 & 192 & 606 \\
\hline${ }^{a}$ S = 'specified'; & ${ }^{b} \mathrm{NS}=$ 'non-specified'. & & &
\end{tabular}

In the group of French-speaking newspapers (Table 3), we observe a potential influence of the total number of published articles or the type of newspaper on the diversity of energy resources that are prominently present in a specific newspaper: the financial newspaper $L^{\prime} E c h o$ published the largest number of articles covering energy options (11), followed by the quality newspapers La Libre Belgique (10) and Le Soir (8), and the popular newspaper La Dernière Heure (6). Further, we observe again strong differences concerning the attention to wind energy: in the popular newspaper onshore wind energy is prominently present in $60 \%$ of the articles, in the 
financial newspaper $L^{\prime} E c h o$, however, onshore wind energy is hardly covered $(1,6 \%$ or three articles). On the other hand, $L^{\prime} E c h o$ has more attention for offshore wind energy $(4,2 \%)$ than for onshore wind energy. Le Soir (25\%) and La Libre Belgique $(22,4 \%)$ have relatively much attention for onshore wind energy. The relatively high scores for natural gas in the French-speaking newspapers can be explained by the relatively strong attention for natural gas in $L^{\prime} E c h o(27,1 \%)$ and Le Soir $(22,3 \%)$.

Focusing on the quality newspapers gives a diffuse image, but between the selected popular newspapers on the one hand and the financial newspapers on the other hand we observe clear similarities. The popular newspapers have strong attention for onshore wind energy and relatively little attention for nuclear energy as prominent energy options. In the group of financial newspapers, we observe an almost complete mirror image of this, and in addition, a clear preference for offshore wind energy over onshore wind energy in a context of low numbers of articles about wind energy in general in comparison with the other newspapers. Furthermore, the financial newspapers are the only ones to give any attention to biofuels. The quality papers Le Soir (22,3\%) and De Morgen (24,2\%), and the financial newspaper $L^{\prime} E c h o(27,1 \%)$ have a relatively strong attention to natural gas.

\subsection{Reporting per type of section}

In order to investigate if the specific newspaper layout has an influence, we have sorted the reporting by type of section. Table 4 shows that the reporting in editorials, letters to the editor and quotes - although there are differences between the newspapers - is rather negligible.

Table 4 . The relations between sections per individual newspaper (\%).

\begin{tabular}{|c|c|c|c|c|c|c|c|c|}
\hline Newspaper & Editorial & $\begin{array}{r}\text { Opinion } \\
\text { piece }\end{array}$ & $\begin{array}{l}\text { Letters to } \\
\text { the editor }\end{array}$ & Interview & $\begin{array}{r}\text { General } \\
\text { news }\end{array}$ & $\begin{array}{l}\text { Local } \\
\text { news }\end{array}$ & Quote & Total \\
\hline $\mathrm{DS}^{a}$ & 1,1 & 2,6 & 0,5 & 3,2 & 67,9 & 22,1 & 2,6 & 190 \\
\hline $\mathrm{DM}^{b}$ & 0,0 & 4,2 & 2,5 & 5,0 & 88,3 & 0,0 & 0,0 & 120 \\
\hline $\mathrm{HLN}^{c}$ & 0,0 & 0,0 & 2,1 & 0,0 & 30,5 & 67,4 & 0,0 & 95 \\
\hline $\mathrm{DT}^{d}$ & 0,6 & 5,3 & 0,6 & 1,8 & 91,7 & 0,0 & 0,0 & 170 \\
\hline $\mathrm{LS}^{e}$ & 0,7 & 2,0 & 0,0 & 4,1 & 58,2 & 33,8 & 1,4 & 148 \\
\hline $\operatorname{LLB}^{f}$ & 0,0 & 2,5 & 1,2 & 1,9 & 65,8 & 28,6 & 0,0 & 161 \\
\hline $\mathrm{LDH}^{g}$ & 0,0 & 0,0 & 0,0 & 1,0 & 25,7 & 73,3 & 0,0 & 105 \\
\hline $\mathrm{L}^{\prime} \mathrm{E}^{h}$ & 2,1 & 2,6 & 0,0 & 4,2 & 90,2 & 0,0 & 1,0 & 192 \\
\hline Total \% & 0,7 & 2,6 & 0,8 & 2,8 & 64,8 & 23,6 & 0,8 & 1181 \\
\hline
\end{tabular}

Regarding interviews and opinion pieces, we observe that popular newspapers do not, or almost never, use these sections to report on energy options. Quality newspapers, however, such as De Morgen (5,0\% and 4,2\% respectively) and Le Soir $(4,1 \%$ and $2 \%$ respectively) and both financial newspapers (L'Echo: $4,2 \%$ and $2,6 \%$ respectively; De Tijd: $1,8 \%$ and 5,3\% respectively), do use interviews and opinion pieces to report on energy resources, but rather limitedly. The data show that either nuclear energy or non-specified renewable energy is central in both sections (no table). Rather important here is the section local news, or more specifically: the 
relation between the number of articles in the sections general news and local news. De Morgen, De Tijd and L'Echo do not have a local section. In this way, the majority of their reporting is found in the section general news. We see the opposite, however, concerning the popular newspapers Het Laatste Nieuws $(67,4 \%)$ and $\mathrm{La}$ Dernière Heure (73,3\%). The quality newspapers De Standaard, La Libre Belgique and Le Soir have a local section that is used to publish on the energy question in Belgium, but these papers primarily report energy issues in the general news section. In the two following tables, we focus on the presence of prominent energy options in the sections general news and local news per newspaper.

Table 5. Energy resources in general reporting (\%).

\begin{tabular}{|c|c|c|c|c|c|c|c|c|c|}
\hline Energy option & $\mathbf{D S}^{a}$ & $\mathbf{D M}^{b}$ & HLN $^{c}$ & $\mathbf{D T}^{d}$ & $\mathbf{L S}^{e}$ & LLB $^{f}$ & LDH $^{g}$ & $\mathbf{L}^{\prime} \mathbf{E}^{h}$ & Average \\
\hline Natural gas & 11,6 & 26,4 & 6,9 & 11,5 & 32,6 & 19,8 & 33,3 & 28,3 & 20,9 \\
\hline Oil & 4,7 & 14,2 & 3,4 & 4,5 & 5,8 & 8,5 & 7,4 & 4,0 & 6,4 \\
\hline Coal & 0,8 & 0,0 & 0,0 & 1,9 & 0,0 & 0,0 & 0,0 & 1,2 & 0,7 \\
\hline Nuclear energy & 23,3 & 22,6 & 27,6 & 32,7 & 20,9 & 40,6 & 25,9 & 30,6 & 28,8 \\
\hline Fossil: NS & 0,0 & 0,0 & 0,0 & 0,0 & 1,2 & 0,9 & 0,0 & 1,2 & 0,5 \\
\hline Biofuels & 0,0 & 0,0 & 0,0 & 2,6 & 0,0 & 0,0 & 0,0 & 1,7 & 0,9 \\
\hline Biomass & 3,1 & 0,9 & 6,9 & 3,2 & 2,3 & 1,9 & 0,0 & 1,2 & 2,2 \\
\hline Geothermal energy & 0,0 & 0,0 & 3,4 & 0,6 & 0,0 & 0,0 & 0,0 & 0,0 & 0,2 \\
\hline Wave power & 1,6 & 0,0 & 3,4 & 0,6 & 0,0 & 0,9 & 0,0 & 0,6 & 0,7 \\
\hline Hydropower & 0,0 & 0,0 & 0,0 & 0,0 & 0,0 & 0,9 & 0,0 & 0,0 & 0,1 \\
\hline Wind energy: Onshore & 2,3 & 1,9 & 3,4 & 1,3 & 2,3 & 4,7 & 7,4 & 1,7 & 2,5 \\
\hline Wind energy: Offshore & 6,2 & 3,8 & 0,0 & 5,8 & 4,7 & 5,7 & 0,0 & 4,0 & 4,7 \\
\hline Wind energy: NS & 4,7 & 0,9 & 0,0 & 1,3 & 1,2 & 0,9 & 0,0 & 1,2 & 1,6 \\
\hline Solar energy & 17,8 & 6,6 & 24,1 & 10,3 & 15,1 & 1,9 & 7,4 & 5,8 & 9,9 \\
\hline Renewable: Other & 0,0 & 1,9 & 0,0 & 1,3 & 0,0 & 0,0 & 3,7 & 0,6 & 0,7 \\
\hline Renewable: NS & 17,1 & 16,0 & 10,3 & 15,4 & 10,5 & 8,5 & 7,4 & 9,8 & 12,7 \\
\hline No energy option & 6,8 & 4,8 & 10,6 & 7,0 & 3,4 & 4,8 & 7,5 & 8,1 & 6,5 \\
\hline Total (absolute): & 129 & 106 & 29 & 156 & 86 & 106 & 27 & 173 & 812 \\
\hline
\end{tabular}

Firstly, Table 5 shows that both popular newspapers hardly report on the energy question in Belgium in the section 'general news'. Secondly, this section largely accounts for the high numbers for natural gas in the quality newspapers De Morgen (26,4\%), Le Soir (32,6\%), La Libre Belgique (19,8\%), but also in the newspapers L'Echo $(28,3 \%)$ and La Dernière Heure (33,3\%). We can observe the same for oil in De Morgen $(14,2 \%)$, for nuclear energy in De Tijd (32,7\%) and La Libre Belgique (40,6\%) and in the popular newspapers La Dernière Heure (25,9\%) and Het Laatste Nieuws (27,6\%) and for solar energy in De Standaard (17,8\%), Het Laatste Nieuws (24,1\%) and Le Soir $(15,1 \%)$. Also in this section, offshore wind energy is prominently present in $D e$ Standaard (6,2\%), De Tijd (5,8\%), Le Soir (4,7\%), La Libre Belgique (5,7\%) and L'Echo $(4,0 \%)$. Finally, attention for biomass is observed in the general section of the financial newspapers (De Tijd 3,2\% and $L^{\prime} E c h o 1,2 \%$ ).

From this, we can conclude that the section general news has a general preference for certain energy options, such as natural gas, oil, solar energy, and nuclear energy. We observe that offshore wind energy is also usually covered in this section, but only in quality and financial newspapers. The less obvious renewable resources are 
mainly present in the general section of the financial newspapers (biofuels, geothermal energy and wave power), but also in the general sections of popular newspapers (geothermal energy and wave power).

Table 6. Energy resources in local reporting (\%).

\begin{tabular}{lrrrrrr}
\hline Energy option & SS $^{a}$ & $\mathbf{H L N}^{b}$ & $\mathbf{L S}^{c}$ & LLB $^{d}$ & LDH $^{e}$ & Average \\
\hline Natural gas & 4,8 & 3,1 & 8,0 & 4,3 & 3,9 & 4,7 \\
Oil & 0,0 & 0,0 & 2,0 & 2,2 & 0,0 & 0,7 \\
Coal & 0,0 & 3,1 & 0,0 & 0,0 & 0,0 & 0,7 \\
Nuclear energy & 19,0 & 7,8 & 4,0 & 6,5 & 5,2 & 7,9 \\
Biomass & 7,1 & 1,6 & 4,0 & 2,2 & 2,6 & 3,2 \\
Tidal power & 2,4 & 0,0 & 0,0 & 0,0 & 0,0 & 0,4 \\
Wave power & 0,0 & 1,6 & 0,0 & 0,0 & 0,0 & 0,4 \\
Hydropower & 0,0 & 0,0 & 0,0 & 2,2 & 0,0 & 0,4 \\
Wind energy: Onshore & 52,4 & 68,8 & 68 & 67,4 & 79,2 & 68,8 \\
Wind energy: Offshore & 2,4 & 3,1 & 0,0 & 0,0 & 0,0 & 1,1 \\
Wind energy: NS & 0,0 & 0,0 & 2,0 & 2,2 & 0,0 & 0,7 \\
Solar energy & 2,4 & 0,0 & 2,0 & 10,9 & 6,5 & 4,3 \\
Renewable: other & 0,0 & 0,0 & 2,0 & 0,0 & 0,0 & 0,4 \\
Renewable: NS & 4,8 & 9,4 & 4,0 & 0,0 & 1,3 & 3,9 \\
No energy option & 4,7 & 1,5 & 4,0 & 2,1 & 1,3 & 2,8 \\
\hline Total (absolute): & 42 & 64 & 50 & 46 & 77 & 279 \\
\hline${ }^{a}$ De Standaard, ${ }^{b}$ Het Laatste Nieuws, ${ }^{c}$ Le Soir, ${ }^{d}$ La Libre Belgique, \\
${ }^{e}$ La Dernière Heure. \\
\multicolumn{7}{c}{. }
\end{tabular}

Table 6 shows the data for the section on local news. Since the quality newspaper De Morgen and the financial newspapers De Tijd and L'Echo do not have a section on local reporting, they are not mentioned in the table. This table shows that the section on local news is the favorite section for popular newspapers to report on the energy question (64 of 95 articles in Het Laatste Nieuws and 77 of 105 articles in La Dernière Heure), but also that onshore wind energy is prominently presented as an energy option in this section (with percentages between 52,4\% and 79,2\%). Further, we observe that quality newspapers with a local section typically use this section to report on the less obvious renewable energy options such as biomass (Le Soir and De Standaard), hydropower (La Libre Belgique) and tidal energy (De Standaard). In the local section, newspapers hardly report on nuclear energy, except for $D e$ Standaard (19\%).

If we link these results to the energy mix in Belgium in 2010, than we observe that the five energy options that dominate the energy question in the investigated newspapers, also play a central role in energy production and consumption. In more detail, especially those energy options that are produced in Belgium, namely nuclear energy and renewable energy, are more strongly represented in the reporting. However, the renewable energy production, that supplies less than a fifth of the energy production in $2010(17 \%)$, consists of more than half of biomass $(9 \%)$. The rest of the renewable energy production comes from hydropower, wind and solar energy, anaerobic digestion and biofuels. This means that the high media attention to wind and solar energy is out of proportion to their use in the Belgian 
energy mix. We observe the opposite for anaerobic digestion, since landfill gas, sediment gas and biogas (in the content analysis classified as 'Renewable: other') are of greater importance in energy production than is suggested by the reporting.

The most significant result in this study is the observation that certain energy resources are systematically more present in certain types of newspapers and/or newspaper sections: the energy question in popular newspapers is mainly covered in the section 'local news' and onshore wind energy is systematically more present in the section 'local news' than other energy options are. This means that popular newspapers mainly publish articles on onshore wind energy, but also that in other (types of) newspapers without a local section, this energy option is hardly present, which consequently has a strong influence on the mutual relations between the energy options. This is observed for both financial newspapers and for the Dutch-speaking quality newspaper De Morgen. Since two Dutch-speaking newspapers, compared to one French-speaking newspaper, have no local section, this seems to explain why the attention for (onshore) wind energy is the biggest difference between the French-speaking and the Dutch-speaking newspapers. Nuclear energy, natural gas, oil, solar energy, offshore wind energy and biofuels are systematically more present in the section 'general news', which may explain why these energy options score higher in newspapers without a local section. This link between types of newspapers and types of newspaper sections on the one hand and prominently present energy options on the other hand is directly related to the news values that are central in a newspaper. The popular newspapers focus more on questions that affect local communities, in this case local conflicts over where to install wind turbines. Financial and quality newspapers have a clear focus on 'hard' political and economic news, which means that energy options, such as nuclear energy, natural gas, oil, solar energy and offshore wind energy, which generally extend beyond the local level, are (more) prominently present. By their nature, offshore wind energy and biofuels that are mainly covered in the financial newspapers, illustrate this even more.

This is confirmed if we take a closer look at the specific events that are covered in the newspapers in 2010. In the case of nuclear energy, the number of articles rises sharply when several political parties and civil society organizations take advantage of the fall of the federal government in 2010 to reopen the debate on whether the oldest nuclear plants should remain in use for a longer period or not. In the case of natural gas, the main event in the reporting is the liberalization of the energy market and its influence on (rising) prices, which causes a strong increase in the reporting in the French-speaking press because of the reopened parliamentary debate on this event. Furthermore, this influence of the political agenda on the prominence of specific energy resources appears to not only explain the relatively strong attention for solar energy in the Dutch-speaking newspapers, but also the strong media attention compared to the limited share of this energy option in the energy production: the subsidies for solar panels for private persons were revised in 2010 by the Flemish Minister for Energy, after a serious political and social controversy about how the over-subsidizing is on the basis of a general rise in the electricity bill on the one hand, and huge profits for companies installing large solar parks on the other hand. The important role of rising consumer prices next to the political agenda is also observed in the case of oil, where increasing prices and their effects on daily life dominate the reporting. Opposite to this, we observe the strong attention from the popular newspapers for onshore wind energy, caused by the 
reporting on the large number of planned onshore wind turbine projects that provoke a lot of local opposition all over the country. Although a lot of projects were covered in the local section of either the Dutch-speaking or the French-speaking press, one much contested project received strong attention both in the Dutch-speaking press and in the French-speaking press because of its location on the language border. This is also confirmed by the relatively larger attention for offshore wind energy and tidal and wave power energy in the Dutch-speaking press compared to the French-speaking press, while only the latter reports on hydropower. These cases suggest that the geographic proximity of the North Sea, or in other words, the regional relevance, influences the newsworthiness of these energy options.

The results also leave open some important questions. Such as the prominence of 'non-specified renewable energy' in the Dutch-speaking financial and quality newspapers, the greater importance of combustion of waste and landfill gas, sediment gas and biogas in the existing energy mix than is suggested in the reporting, and the atypical profile of the quality newspaper De Morgen: in comparison with the other quality newspapers, De Morgen published significantly fewer articles, that are characterized by a small, but remarkable, diversity of energy resources, with a lot of attention for fossil energy options and nuclear energy and with notably less attention for specific renewable energy options.

This study is the first to investigate the media representation of the diversity of and mutual relations between the existing energy options in a specific temporal-spatial context. In this way it serves as an exploratory study with the aim of establishing a first view of the social debate on the energy question in Belgium. More specifically, it was able to reveal the extent to which a wide range of newspapers report on the various existing energy options, thereby allowing us to draw conclusions on the range of energy options which are discussed and how this relates to particular journalistic features and choices. However, to be able to draw conclusions on how these representations potentially influence the social acceptance of and support for a specific energy future, more research is urgently needed.

On the one hand, we need more information on the exact nature of these representations in terms of more profound quantitative research or qualitative discourse analytic research, which also allows an analysis of how specific energy options and actors, themes, arguments, and courses of action are represented. In this way, answers can be obtained to how 'event-driven' the reporting on certain energy options really is and which actors and arguments correlate with a stronger (or lower) attention for specific energy options. The analysis above of the specific events that were central in the reporting suggested both a strong influence of political discussion and disagreement on the extent of media attention (nuclear energy, natural gas and solar energy) and of rising consumer prices (natural gas, solar energy and oil). This should also enable a better insight in the reason for the remarkable attention in De Morgen to fossil energy options and nuclear energy as opposed to renewable energy options. Preceding research has shown that $D e$ Morgen in regard to environmental reporting is characterized by progressive reporting, making this attention to fossil energy particularly surprising [Maeseele, 2011]. A study exploring whether the attention to fossil energy options and nuclear energy is mainly negative or not would add further insight here. Moreover, attention needs to be given to what extent and how different energy options are 
covered in terms of different social criteria, such as affordability, reliability (supply security), environmental and health impact and spatial impact. Furthermore, longitudinal research is needed to obtain a better insight into the moment when and the manner how certain energy options became more important in the social debate and were considered a 'realistic' alternative. Equally, international comparative research on these questions, both in a European and an international context is also warranted. Finally, the mediascapes of the $21^{\text {st }}$ century urgently call for research beyond print media, including online and social media. More specifically, independent, alternative online news media have increasingly been found to arise on the web in response to the perceived deficiencies of professionalized-commercial news media. Differentiating themselves from mainstream media in terms of organization, professional practices and ideological orientation, these online news sites have been found to give the floor to neglected voices, ideas and courses of action [Pepermans and Maeseele, 2014].

On the other hand, to evaluate the influence of these representations on other aspects of social debate, such as the course of political discussions or the level of public knowledge and acceptance of specific energy options, or a specific energy future, other data than media data are required, such as parliamentary discussions or interviews, survey's or focus groups with either politicians, stakeholders or citizens.

Author's note and funding
The authors received financial support from the energy company, Electrabel-GDF Suez, which funded a scientific research project on the representation of the energy question in the Belgian daily press during 2011. Although this research was supported by Electrabel- GDF Suez, the opinions, findings, conclusions, or recommendations expressed in this publication are those of the authors and do not necessarily reflect the views of Electrabel-GDF Suez.

Beck, U. (1992). Risk Society. Towards a new Modernity. London/Thousand Oakes (CA)/New Delhi: Sage Publications.

Bickerstaff, K., Lorenzoni, I., Pidgeon, N.F., Poortinga, W. and Simmons, P. (2008). 'Reframing nuclear power in the U.K. energy debate: nuclear power, climate change mitigation and radioactive waste'. Pub. Underst. Sci. 17, pp. 145-169.

Bolsen, T. (2011). 'The construction of news: Energy crisis, advocacy messages, and frames toward conservation'. International Journal of Press-Politics 16, pp. 143-162.

Commission of the European Communities (2006). A European Strategy for Sustainable, Competitive and Secure Energy, Green paper. Brussels, Belgium.

Culley, M.R., Ogley-Oliver, E., Carton, A.D. and Street, J.C. (2010). 'Media framing of proposed nuclear reactors: An analysis of print media'. Journal of Community and Applied Social Psychology 20, pp. 497-512.

Doyle, J. (2011). 'Acclimatizing nuclear? Climate change, nuclear power and the reframing of risk in the U.K. news media'. International Communication Gazette $73(1)$, pp. 07-125.

Economie, FOD (2013). 'Het energieoverleg tussen de staat en de gewesten [The energy consultation between federal government and regions'. URL: http://economie.fgov.be/nl/consument/Energie/Politique_energetique/ Contexte_Belge/Het_energieoverleg_tussen_staat_en_gewesten/. 
Gamson, W.A. and Modigliani, A. (1989). 'Media discourse and public opinion on nuclear power: A constructionist approach'. American Journal of Sociology 95, pp. 1-37.

Ganzevles, J. and Van Est, R., eds. (2011). Energie in 2030. Maatschappelijke keuzes van nu [Energy in 2030. Today's Social Choices]. Boxtel, The Netherlands: Aeneas.

Kepplinger, H.M. and Roth, H. (1979). 'Creating a crisis: German mass media and oil supply in 1973-74'. Public Opinon Quarterly 43, pp. 285-296.

Lambeth, E.B. (1978). 'Perceived influence of the press on energy policy making'. Journalism Quarterly 55, pp. 11-72.

Maeseele, P. (2011). 'On news media and democratic debate: framing agricultural biotechnology in Northern Belgium'. International Communication Gazette 73, pp. 83-105.

- (2013). On Media and Science in Late Modern Societies. Ed. by E. Cohen. New York, U.S.A., pp. 154-181.

Mazur, A. (1990). 'Nuclear power, chemical hazards, and the quantity of reporting'. Minerva 28, pp. 294-323.

Murphree, V. and Aucoin, J. (2010). 'The energy crisis and the media: Mobil Oil Corporation's debate with the media 1973-1983'. American Journalism 27, pp. 7-30.

Nadar, L. (2010). The energy reader. Malden, MA, U.S.A.: Wiley and Sons.

Nerlich, B. and Koteyko, N. (2009). 'Carbon reduction activism in the U.K.: Lexical creativity and lexical framing in the context of climate change'. Environmental Communication 3, pp. 206-223.

Pepermans, Y. and Maeseele, P. (2014). ‘Democratic debate and mediated discourses on climate change: from consensus to de/politicization'. Environmental Communication 8, pp. 216-232.

Qu, M., Tahvanainen, L., Ahponen, P. and Pelkonen, P. (2009). 'Bio-energy in China: Content analysis of news articles on Chinese professional internet platforms'. Energy Policy 37, pp. 2300-2309.

Schafraad, P., Wester, F. and Scheepers, P. (2006). 'Using 'new' data sources for 'old' newspaper research: Developing guidelines for data collection'. Communications 31, pp. $455-67$.

Sovacool, B.K. (2013). Energy and ethics: justice and the global energy challenge. New York, U.S.A.: Palgrave Mac-Millan.

Spreng, D., Flüeler, T., Goldblatt, D.L. and Minsch, J., eds. (2012). Tackling long-term global energy problems. The contribution of social science. Dordrecht, The Netherlands: Springer.

Stephens, J.C., Rand, G.M. and Melnick, L.L. (2009). 'Wind energy in US media: A comparative state-level analysis of a critical climate change mitigation technology'. Environmental Communication 3, pp. 168-190.

Stephens, M. and Edison, N.G. (1982). 'News media coverage of issues during the accident at Three-Mile Island'. Journalism Quarterly 59, pp. 199-204.

Wathelet, M. (2012). Algemene beleidsnota energie, leefmilieu en mobiliteit [General policy note of energy, environment and mobility]. Brussels, Belgium: Belgische Kamer van Volksvertegenwoordigers. 
Pieter Maeseele (PhD Ghent University) is Research Professor at the Department of Communication Studies of the University of Antwerp (Belgium). As media sociologist, his research and teaching focuses on Science, Media \& Democracy, and more specifically on the contribution of public discourse about science and environment to democratic debate and citizenship. The role of ideology and $\mathrm{de} /$ politicization, and their influence on pluralism, are central concerns. E-mail: Pieter.Maeseele@UAntwerpen.be.

Karel Deneckere is PhD-student and teaching assistant at the department of communication studies at the Free University of Brussels. His PhD-dissertation will be on the media representation of the nuclear energy issue in Belgian, which he approaches mainly from a discourse theoretical perspective. He is member of research centre Desire (Centre for Democracy, Resistance and Signification). E-mail: Karel.Deneckere@vub.ac.be.

Koen Panis, $\mathrm{PhD}$, is a postdoctoral researcher and part-time lecturer at the Department of Communication Studies at the University of Antwerp. He is member of the research group Media, Policy and Culture (MPC). He is also a part-time lecturer at the Erasmus University Rotterdam. In his research, he mainly applies quantitative research methods on a variety of media topics such as celebrity, television and media concentration. E-mail: Koen.Panis@UAntwerpen.be.

Steve Paulussen, $\mathrm{PhD}$, is an assistant professor in media and journalism at the Department of Communication Studies at the University of Antwerp. He is member of the research group Media, Policy and Culture (MPC). Most of his research is situated in the scholarly field of journalism studies. He is the (co-)author of various publications in scientific journals and books on different aspects of online journalism, participatory journalism, the professional profile of journalists, new media consumption and newsroom innovation.

E-mail: Steve.Paulussen@UAntwerpen.be.

How to cite

This article is licensed under the terms of the Creative Commons Attribution - NonCommercial NoDerivativeWorks 4.0 License.

ISSN 1824 - 2049. Published by SISSA Medialab. http://jcom.sissa.it/. 